\title{
9/11 - The Rebirth of the Myth of the American Hero and Feminism
}

\section{Rita Santos}

\section{Abstract:}

This paper examines the impact of $9 / 11$ on the American imaginary and the ways in which old myths of the American hero have been rehashed in the aftermath of the attacks. Using Susan Faludi's The Terror Dream: What 9/11 Revealed about America as the main object of study, the repercussions this resurgence of American mythical constructions had on women and feminist discourse will be explored. The purpose of the paper is to demonstrate how prejudice against women is deeply ingrained in the American hero myth narratives and how it gains momentum in times of crisis, revealing an internalized misogyny.

Keywords: 9/11, captivity narratives, American hero, American myths, feminism.

\section{Resumo:}

Este trabalho analisa o impacto do 11 de setembro no imaginário americano e a forma como velhos mitos do herói americano renasceram após os ata ques. Com a obra de Susan Faludi, The Terror Dream: What 9/11 Revealed about America, como principal objeto de estudo, as repercussões que este ressurgimento das construções míticas americanas tiveram nas mulheres e no discurso feminista serão exploradas. $O$ objetivo do trabalho é demonstrar a forma como o preconceito contra as mulheres está profundamente entranhado nas narrativas do mito do herói americano e como este ganha ímpeto em momentos de crise, revelando uma misoginia internalizada.

Palavras-chave: 9/11, narrativas de cativeiro, herói americano, mitos americanos, feminismo.

\section{Introduction}

The attacks of September 11, 2001 remain as one of the most traumatic events in American history. With Susan Faludi's The Terror Dream: What 9/11 Revealed about America as my main reference, in this paper I explore the ways in which 9/11 trauma may have awoken old myths present in the American imaginary, giving way to the rebirth of the American hero/John Wayne-esque myth. I then explore the implications this new construction of the American hero had on feminism and which role was attributed to women afterward.

I start by providing a general framework on the notions of collective and cultural trauma in order to understand the recourse to the past. Then I will focus on how 
captivity narratives set a pattern for the hero/victim dichotomy and women's passive role in times of crisis. After exploring the ways in which feminism and feminists were attacked and partially blamed for the attacks, I will move onto the consequences of such beliefs. Afterwards, I will delve into all the ways 9/11 affected the heroicization process in American society and culture and how that process ended up pushing women into the private sphere while men were driven to the public sphere. Finally, I will analyze the ways in which the American hero myth is currently portrayed and how those portrayals affect women's role in these mythical constructions.

\section{Trauma: grasping the past to make sense of the present}

When discussing trauma, some authors make the mistake of having in mind only individual events. One of the authors who is known for focusing on the difference between individual trauma and collective trauma is Kai Erikson. He defines individual trauma as "a blow to the psyche that breaks through one's defenses so suddenly and with such brutal force that one cannot react to it effectively" (Erikson, 1976: 153 cited by Alexander, 2004: 4) while by collective trauma he means "a blow to the basic tissues of social life that damages the bonds attaching people together and impairs the prevailing sense of communality" (Erikson, 1976: 153-54 cited by Alexander, 2004: 4).

The exploration of collective trauma focuses mainly on the feelings of powerlessness and hopelessness that consume and affect the sense of collective self. In this way, the main difference between individual trauma and collective trauma is that the latter has more extended repercussions, affecting the main structures of a community while the former is singular, putting at stake a single individual's relationships and personal identity.

The events of September 11, 2001 are part of a collective trauma. Although they represent crimes committed against individuals, they targeted the American community. Therefore, it is essential to briefly explore the notion of collective trauma in order to understand the impact that the events had on the American sense of self. Ganzevoort and Veerman discuss the effects that collective trauma has on the way the damaged community relates to other communities: "Common phenomena are withdrawal and isolation, identifying enemies and scapegoating, or surrendering to 
external forces" (2001: 5). The American people became more isolated after the events, with high levels of mistrust and wariness taking over their community. Furthermore, the identification of enemies was also easily achieved by holding grudges against Muslims.

When talking about collective trauma, it's impossible not to think about culture. Trauma and culture are connected and collective trauma will reveal just that intricate connection. Whenever an event brings pain and trauma to individuals of a community, the pain and grief is collective because of their shared culture. Culture is the glue bringing trauma and community together. Both concepts are intrinsically associated not only to each other, but also to the notion of identity (both of the community and of the individuals who belong to it). When faced with the aftermath of cultural trauma, the sense of community identity may be either strengthened or disrupted (Baelo-Allué, 2012: 64). This reveals that culture will play a vital role in the overcoming of the collective trauma.

Given the traumatic nature of the 9/11 events, the entire phenomenon was difficult to understand or explain. Therefore, in an attempt to make sense of what was happening around them, it is normal that Americans looked at history and tried to hold onto historical and national myths to try to grasp some conclusions out of it and make sense of what had happened.

\section{From captivity narratives to John Wayne}

Nancy Gibbs' words in Time Magazine in October, 2001 revealed very clearly this connection between culture, trauma, identity and the past, by stating "we are seeing it in our nation and sensing it in ourselves, a new faith in our oldest values" (2001). Included in these values are also the national myths and narratives that played such a decisive role in Puritan America and its subsequent heritage to contemporary North America. Among some of the most important contributors to these myths are the captivity narratives of the 17 th century, taking us back to the early core of Puritan society. According to Richard Slotkin:

In [a captivity narrative] a single individual, usually a woman, stands passively under the strokes of evil, awaiting rescue by the grace of God. The sufferer represents the whole, chastened body of Puritan society; and the temporary bondage of the captive to the Indian is dual paradigm - of the 
bondage of the soul to the flesh and the temptations arising from originalsin, and of the self-exile of the English Israel from England. In the Indian's devilish clutches, the captive had to meet and reject the temptation of Indian marriage and/or the Indian's "cannibal" Eucharist. (Slotkin, 1996: 94)

These narratives played a crucial role in the American imaginary because they set a pattern for the hero/victim dichotomy still present in the world of today. In the Indian captivity narratives in early Puritan America, women were captured by the Native Americans and held captive by them. These narratives not only had an important impact on the establishment of a European-American identity, but they also illustrated how women were "doubly victimized" in Puritan America: they were captured and held as prisoners by the Indians, but their stories were then used as propaganda to demonize the Indians (Derounian-Stodola, 1994: 33). A similar phenomenon would happen again with the Afghans and Iraqis after 9/11 under the Bush Administration, as I will focus on, ahead in this paper.

Furthermore, captivity narratives helped shaping the role of women in the American Puritan society, a role which was already oppressing and submissive, totally devoid of any powerful position in the state and in the church. As a result, women started being seen as victims in need of rescue. This was an idea that persisted in the American imaginary until today. Due to length constraints, I will not discuss the evolution of this notion, but it is important to have in mind that there was a resurgence of this myth mainly in the 1950s. This revival may have been caused by the significant turn in the feminist movement during WWII, when women were pushed to work outside of their homes to occupy the jobs left vacant by men who were fighting in the war. Although once the war was over they were encouraged to get back to their domestic life and dedicate their lives to their families, many women continued to work outside the home. Even the 1950s media promoted the idea that men would only regain their masculinity if women reclaimed their femininity (Faludi, 2007:282). Such notion was expanded to Hollywood, where the film The Searchers, with John Wayne, became the basis of all Hollywood films of the time, carrying and exacerbating the national myth of the happy ending where the good guys prevail over the bad guys and save the girl.

Due to the characters he portrayed, John Wayne became one of the true American heroes. Still today, his popularity in the US is a remarkable phenomenon to be 
witnessed. When asking Americans who their "favorite star" is, John Wayne's name is the only one appearing on the annual Harris poll since it first began, in 1994. On the poll conducted in 2014, John Wayne remained the favorite star among men and conservatives. These are interesting results which allow us to understand even better how these core values are still present in the American imaginary (Shannon-Missal, 2015). In my view, the Golden Age of comic books (from the 1930 s to early 1950s) and the consequent rising popularity of the superhero archetype were also important contributors that allowed for this John Wayne myth to gain momentum, as I will explore later on in this paper.

After the events of $9 / 11$, while facing terror, the US clung to what has always been thought to be its best formula of security - by living immersed in mythical fiction instead of reality. This generated a series of mechanisms diverting people from the real problem - US foreign policy. Instead of trying to understand why the attacks had happened and how the US could be partially responsible for them, the US saw itself as the ultimate victim, as the ever so often reckless comparisons to the Holocaust prove. As I will explain, in doing so, the US chose to turn the 9/11 into a domestic issue, with the feminist influence being a major culprit of the current American vulnerability. This caused a major uproar of attacks to feminism and female voices who dared to call out its attention to this issue.

\section{Backlash against Feminism}

According to Faludi, days after the attacks, feminism and feminists became one of the main targets in the media. For some reason, everything that had gone down at the World Trade Center and the Pentagon had proved how female independence should be disclaimed. Perhaps the most striking examples of such attacks are those of Rev. Jerry Falwell, who said that

The abortionists have got to bear some burden for this because God will not be mocked. And when we destroy 40 million little innocent babies, we make God mad. I really believe that the pagans, and the abortionists, and the feminists, and the gays and the lesbians who areactively trying to make that an alternative lifestyle, the ACLU, People for the American Way, all of them who have tried to secularize America, I point the finger in their face and say, 'You helped this happen.' (Goldstein, 2001) 
Although the following opinions are strictly directed at feminism, they are just as prejudiced as those of Falwell's. Cathy Young (2002) believes that "after years of malebashing, it is good to see some appreciation for male heroism and even for the fact that traditional machismo always included not only dominance but protection and rescue", while Mona Charen (2001) states that "perhaps the new climate of danger danger from evil men - will quiet the anti-male agitation we've endured for so long."

One can only understand these positions by referencing something Faludi doesn't acknowledge - that the misconception of the term feminism is the root of such dubious statements. If the term feminism were not in a continuous process of pejorization, its meaning would not have the degrading connotations that encouraged Falwell, Young or Charen to believe they were stating universal truths. Feminism, as a movement, does not promote male hatred or bashing, nor does it associate men with evil forces.

Despite disregarding the misconception of the term feminism, Faludi argues that these positions come from the fact that, in the perspective of this particular group of people, feminism has "softened" men in the US. It's interesting how this already challenging claim has another problematic notion associated to it: that "femininity" stands for weakness, fragility and vulnerability while strength, power and roughness are associated with "masculinity".

During times of indecision, changes on any spectrum are often feared. With feminism being one of the most prominent social changes, this fear held by the American society toward feminists would not only lead to attacks on them, but also to the silencing of female voices in general.

\section{Silencing of Female Voices}

According to an analysis of the newspaper Guardian, there was a significant drop of female representation on television and newspapers right after 9/11 (Bunting, 2001), with white men dominating the public opinion. Faludi successfully presents examples that confirm this male favoritism, from which the most striking one is perhaps a study on the female representation in Sunday talk shows that revealed a drop of $40 \%$ in the number of appearances by American women (2007: 35-6). It is important to clarify that 
not all women were silenced, but even those who had the opportunity to have their voices heard became the target of abusive and sordid name-calling. Susan Sontag's provocative article for The New Yorker on September 24, 2001, where she suggested that the attacks were a response to the controversial and problematic US foreign policies, instantly warranted her with a panoply of insults. Magazine editors and columnists called her "deranged" and "an ally of evil", accused her of suffering from "moral idiocy" and of "hating America and the West and freedom and democratic goodness" (Faludi, 2007: 27). It is interesting to note how there were left-wing men who were just as provocative and critical as Sontag (such as Gore Vidal and Bill Maher) and yet they were not nearly as insulted as Sontag.

Although Faludi extensively explores how women were ignored, I have identified two main problems in her analysis. While she is successful providing us with examples of female opinions on the events, she could have focused more on the women who actually died on that day and whose courageous acts were either ignored or forgotten while men were elevated to hero status. For example, in the following weeks after the attacks, Eileen Shulock, an unemployed woman at the time, decided to use all of her internet knowledge and managed to recruit online 3000 volunteers for rescue agencies, such as the Red Cross and the United Way (Dollarhide, 2001a). Rosemary George, an African-American ironworker, was called to help clear the site of the collapsed World Trade Center and put her own life at risk by spending three days digging through the rubble and clearing debris with her own hands in search of survivors (Dollarhide, 2001b). These are just some of the examples Faludi could have mentioned in her book. I will talk about other brave women of 9/11 later on in this paper, when analyzing the way male firefighters and police officers were heroicized.

However, even when Faludi is not centering her attention on the women who perished that day, the examples she chose to talk about could be more inclusive and intersectional, which constitutes the second problem in her analysis. For instance, at a certain point Faludi mentions how even feminists "across the border" weren't safe from criticism, giving only an example of a Canadian columnist for the Toronto Star (2007: 32). Were there no opinions by female Latin Americans on the 9/11 that Faludi could have mentioned? Nonetheless, this does not mean that the author completely 
neglects women who, in the center/margin dichotomy, do not belong to the center. Faludi references Anastasia Soare (2007: 120), a Romanian woman who has become an icon in the American beauty industry, and Belen Aranda-Alvarado, a Latin-American member of the Harvard Business School (2007: 132). Still, when it comes to accounts of the actual survivors or their relatives, the stories chosen by Faludi refer to white middle-class women. Given the wide array of information on how minorities were subjected to exponential levels of discrimination in the aftermath of 9/11, I wonder why Faludi did not address this double invisibility of women who belong to the margins and how their silencing greatly contributed for the general lack of female voices being heard.

In 2011, Time Magazine published a photographic commemorative edition of the 10th anniversary of the attacks. Despite the twelve African-American firefighters who perished on that day, there were no pictures of African-Americans in Time's remembrance issue. When faced with such situation, the mothers of these firefighters decided to struggle to keep their sons' memories alive (Prince, 2011).

Luz Maria Mendonza is a Mexican widow whose husband, Juan Ortega, died during the attacks. Because Ortega was an undocumented migrant, his wife struggled for several years of overlooking to prove that he worked at the World Trade Center (Good, 2011).

After losing her partner, Sheila Hein, in the terrorist attack on the Pentagon, Peggy Neff was denied compensation by Virginia's Criminal Injuries Compensation Fund, a decision that had solely to do with the fact that same-sex partners do not have the same rights as heterosexual couples (Lombardi, 2002).

The three examples given above did not receive the same amount of attention and exposure as several other stories of white middle-class families of the victims coping with their losses. Addressing such situations (or those with similar outlines) would have made Faludi's argument more diverse and intersectional. By also silencing the voices of minorities, Faludi ends up putting to practice what she accused the US of doing.

Surprisingly enough, at the same time female voices were being silenced and ignored, the Bush Administration tried to take advantage of women's rights to 
legitimate the US welfare interventions as a response to the 9/11 attacks. Gender has always been an efficient tool to legitimize war and national security (Tickner, 2002: 336), a point also highlighted by Susan Faludi. George W. Bush used women's liberation in a rather opportunist attempt to gather more supporters on the Afghanistan invasion, by presenting the inexistent education of Afghan women as one of the reasons why the US should intervene in that country. It is also interesting to note the importance and influence of the First Lady during this campaign. In November 2001, Laura Bush used the President's weekly radio address to call out attention to the "brutality against women and children by the al-Qaida terrorist network and the regime it supports in Afghanistan, the Taliban" (2001). One may conclude that a female voice talking about other women's rights would have a greater emotional impact on other women.

Nonetheless, this concern about women's rights proved to be disingenuous when Bush supported Afghan president Hamid Karzai, who would later be responsible for the passing of laws that allow husbands to deny wives food if they fail to follow their sexual demands (Boone, 2009). In addition to this, once the war started, there were suddenly no more mentions to the Afghan women's liberation movement, proving just how much Bush's real interests did not lie on women's rights.

One piece of information that may seem contradictory, and that Faludi does not mention, is how the Bush Administration was one of the most gender diverse in history, until Obama's first term (Page, 2004). However, regardless of this diversity, what is truly important to retain is to look at the political decisions favoring women and other minorities, an aspect that doesn't favor the Bush Administration in the slightest. From supporting anti-feminist organizations to shutting down women's offices in the government, we are able to conclude that Bush was likely trying to take advantage of such a demonstration of inclusiveness to gain popularity amongst women and other minorities. But regardless of his intentions, these people still had positions of power in the White House and such fact should not have been disregarded by Faludi when discussing the ways in which women have become invisible in a post 9/11 US. Such invisibility, however, would become especially noticeable when compared to the elevation of men as heroes. 


\section{9/11 and the rebirth of the myth of the American Hero}

Besides silencing women, the trauma of $9 / 11$ also contributed to the reemergence of the notion of the American hero, in what Faludi describes as a promotion of "American chivalry". Unsurprisingly, the main character trait of the American hero was his manliness, in a revival of the problematic equation of manliness and masculinity with power and strength.

All over the country, "manly man" politicians and other powerful figures, such as George W. Bush, Donald Rumsfeld, Dick Cheney and Rudy Giuliani, had their bodies and faces edited in magazines to make them look like superheroes (Faludi, 2007).

9/11 attained a mythic stamp from the very beginning in the way President George W. Bush handled the situation. Disregarding any possible connection between the events and US foreign policy, Bush was quick to assert that "America was targeted for attack because we're the brightest beacon for freedom and opportunity in the world." (2001). From here on, Bush was known to acquire a dualistic and one-dimensional view of the events, where the US stood for good and the terrorists stood for evil. According to Faludi, this "cartoonish" comic book storyline where Americans were the heroes and the terrorists the villains helped Bush in gaining more supporters (2007: 47). This is in direct dialogue with what I mentioned earlier in this paper: that the myths brought along with this 'cartoonization' of the events and the role of comic books, together with the heritage of the captivity narratives, were the two main factors contributing to the resurgence of the John Wayne myth of the American hero.

An interesting trend right after the attacks was the way in which the event affected the comic book and cartoon industry. To help people cope, the responses from this industry took a variety of forms and appeared shortly after September 11, with DC Comics and Marvel releasing projects related to the events. This trend was highly visible in other forms of popular culture, expanding to television and cinema. Television shows like Heroes, Lost and 24 offered this "manly man" representation of heroes. In cinema, there was a new wave of superhero movies in the 2000s, with the X-Men series, Spider-Man, Daredevil, Batman and Catwoman, just to name a few. Meanwhile, in the series of the most iconic characters in the comic book universe, 
superheroes were portrayed as being powerless, in an attempt to make these characters more relatable to the American people through the transposition of their recent fragility to the classic ultimate heroes.

However, at the same time that the established fictional superheroes were portrayed as powerless, in real life the "manly man" John Wayne-esque hero prevailed. Faludi describes this phenomenon as a "reversal in hero worship", where Superman and co. were replaced by ordinary people in the true American hero podium (2007: 51). But who were these heroes "of its own" in the US after 9/11? And what role did women play in this new redistribution of heroism?

Joseph Campbell, an authority on superhero mythology, developed the concept of Classical Monomyth: "A hero ventures forth from the world of common day into a region of supernatural wonder: fabulous forces are there encountered and a decisive victory is won: the hero comes back from this mysterious adventure with the power to bestow boons on his fellow man" (Campbell, 1956: 30 quoted in Jewett and Lawrence, 2002: 6).

Borrowing from this definition, Robert Jewett and John Shelton Lawrence argued for an American variation of this concept, naming it "The American Monomyth":

A community in a harmonious paradise is threatened by evil; normal institutions fail to contend with this threat; a selfless superhero emerges to renounce temptations and carry out the redemptive task; aided by fate, his decisive victory restores the community to its paradisiacal condition (Jewett and Lawrence, 2002: 6).

In this concept proposed by Jewett and Lawrence the presence of the John Wayne myth is also visible in this "selfless superhero" who saves the day and defeats evil. But how did 9/11 fit in this "American Monomyth" narrative?

Police officers, firefighters and citizens who offered their efforts to help those struggling with the terror taking place on the Ground Zero and the Pentagon were instantly on the front page of newspapers and featured on TV. These were the John Waynes of our time - the noble, heroic and regular strong "macho men" of the New York Police Department (NYPD), the Fire Department of New York (FDNY) and the citizens who selflessly put their lives at risk to save as many people as possible. Even if many perished and were not able to "restore the community to its paradisiacal 
condition", their efforts were still considered courageous and heroic. However, amidst this heroicization process, one has to wonder where the "Jane" Waynes were.

After 9/11, while men were elevated to heroes, women were relegated to forgetfulness. Most of the stories being publicized in the weeks following the attacks featured men as the gallant rescuers, mainly of women. Just to provide an example, this was particularly visible in the story with high media coverage of how a group of firefighters inside the North tower of the World Trade Center refused to leave a woman behind even when the tower was collapsing, saving her life in the process (Inside the Twin Towers, 2006). This association of action and bravery with masculinity while passivity and helplessness equate femininity is another important heritage of the myths originated from the captivity narratives I have explored in the beginning of this paper. As a result, this ever-growing tendency to equate masculinity with action and heroism while femininity was associated with passivity and helplessness, eclipsed the efforts of many women who, on that day, were just as brave and courageous as their male counterparts.

One year after the attacks, Lt. Brenda Berkman, a veteran New York City firefighter, pointed out that the disregarding of women firefighters was so common that the sexism had spread to language, with the term "fireman" returning to vogue (Miller, 2002). Berkman was one of the many women firefighters who expressed her resentment on the way so many of the female fearless acts on that day went unnoticed: "Women were down there from the time that the first plane hit the first tower [...] Women were trapped in the rubble. Three women rescue workers were killed that day", including paramedic Yamel Merino, Port Authority Capt. Kathy Mazza and police officer Moira Smith. According to witness accounts, the last two women displayed great bravery that day. Mazza is said to have oriented her officers on the World Trade Center, where they were killed while trying to carry a woman out of the building. After helping an injured man out of the World Trade Center, Moira Smith ran back into the South Tower, and was later killed in the collapse while trying to rescue other people (Drexler, 2002). Smith was even photographed moments before returning to the South Tower, but that still did not prevent her story to be considerably less covered or promoted than those of her male colleagues. As Berkman put it: "I've 
been a firefighter for 20 years and l've never seen the contribution of women firefighters, police officers and paramedics so completely ignored. Suddenly, we've become invisible. It's as though we were wearing the American equivalent of the veil." (Berkman, 2001 quoted by Faludi, 2007: 82)

Faludi calls our attention to the fact that, despite 75 to $80 \%$ of the $9 / 11$ victims being men (CNN Library, 2015), the several images of men rescuing women could be deceptive. Despite this, it would be false to claim women were completely silenced or ignored. There were instances where women were the main focus of attention. I will explore next how even in those occasions of apparent protagonism, women kept being pushed to the private sphere.

\section{Female survivors, Male heroes}

In the months after the attacks, the media focused most of their attention on the families of the victims, trying to understand how they were coping with their losses. This coverage, however, was not equally distributed and, unlike what was happening with the construction of the narratives of the 9/11 heroes, women became the center of all attention. The stories of pregnant widows whose babies were going to be born after the death of their fathers were the preferential option for headlines and newspaper covers. In 2002, People magazine even organized a photo shoot in New York, gathering 9/11 widows and their newborn babies for a group photo (Faludi, 2007: 95). Nevertheless, the $9 / 11$ widowers became invisible. Their stories were not as widely distributed as those of the widows and they certainly were not given the chance to take a group photo with other widowers and their children. Despite this, the narratives that now pushed women to the foreground (and men to the background) were focused solely on their role as mothers and wives. In this situation, the media attention was on women while men in a similar position were being dismissed. However, since the reasons that pushed women to public attention were led by their private sphere role of family caretakers, it can be argued that, despite now being in leading roles in the media, the essence of that protagonism still pushed women to the private sphere. A good example of this was Lisa Beamer, wife of Todd Beamer, one of the Flight 93 passengers who was proclaimed a hero. After learning she was pregnant 
by the time of the attacks, reporters hounded her. Regardless of her cooperation in being in the spotlight, all the questions directed at her were extremely personal and intrusive, as Faludi illustrates: "This Christmas doesn't it make you sadder? [...] Now, how do the boys like having a little sister? [...] Does she sleep well at night? [...] What do you have, one boy in a bed and two in cribs now?" (King, 2001 cited by Faludi, 2007: 100-1).

All these questions revolving around Lisa Beamer demonstrate this obsession of the American media in portraying the 9/11 widows as perfect suburban wives. Those who did not engage with the media were then warranted with public judgments on the way they were spending their money: "They seized on rumors about widows who supposedly had face-lifts, Botox injections, breast implants, and cosmetic surgery one was even said to have gone under the knife 'on her wedding anniversary'" (Faludi, 2007: 104).

This attempt to push women into the private sphere fits the portrayal of men as heroes and women as victims, resulting in the idea of the woman in distress who needs to be protected by the fierce man.

With this new resurgence of the American hero and its misogynist consequences that jolted women into the private sphere, it is important to now explore how all the processes exposed so far in this paper have changed since 2001. I will try to show what shape the American hero myth is currently taking and what the implications for feminism are.

\section{What about today?}

Earlier on in this paper I have talked about the pejorization of the term "feminism". Unfortunately, there have been no significant changes in this process that encourages people worldwide to distance themselves from "the F word". To this very moment there are campaigns comparing feminists to terrorists, where the most bizarre example of that association is a petition circulating online whose goal is to officially consider feminism as a terrorist movement (Wilkinson, 2015). On social media there have been movements, such as "Why I don't need feminism" or "I need meninism because..." where both men and women talk about everything but what feminism truly 
stands for. Overall, feminism is still acknowledged as a bad word that is understood as a synonym for misandry.

Just like feminists were to blame for the American male "softness" registered pre9/11, today feminists are blamed for a whole new variety of events. Just to give some of the most controversial examples: earlier this year, a catholic Cardinal stated that "radical feminism" was to blame for pedophile acts by priests (Ferguson, 2015). He argued that feminists were responsible for the current established "fluffy" view of sexuality, making way to pedophile priests. According to Charlotte Allen, the lack of male aggression in the "feminized setting [that] is a setting in which helpless passivity is the norm" at Sandy Hook Elementary was an important factor that allowed for the shooting to take place (Allen, 2012).

In 2007, when talking about the silencing of female voices on the media after 9/11, Rebecca Traister accused Faludi of focusing only on the side that better serves her interests. She claimed that during the years mentioned by Faludi, there were women occupying positions of power in the media, such as Jill Abramson and Ariel Levy, among others (Traister, 2007). However, just as Faludi should look at the big picture instead of generalizing, so should Rebecca Traister. According to the Women's Media Center, gender representations statistics from 2014 show that, in newspaper newsrooms, women occupied only $37.2 \%$ of the positions. This is actually $0.01 \%$ less compared to the numbers gathered in 2001. The report also demonstrates how gender inequality among journalists, whether online, on television or in print, still persists. The results reveal that men dominate media by $62.1 \%$ against women's $37.3 \%$ (Women's Media Center, 2015). While I could not get access to reliable statistics on the US media gender gap in 2001, what is important to retain is that these numbers are still troublesome. Little has changed since 2012, when the first report by the Women's Media Center came out. It is a reality that women are still underrepresented on the US media and, as a result, female voices are still being silenced, allowing for Faludi's argument to be taken in consideration.

Considering my earlier focus on the way 9/11 affected female firefighters and police officers, I think it is relevant to look at the current number of women present in the FDNY and the NYPD. In FDNY, as of May 2015, out of 10,500 firefighters, there were 46 
women, constituting an historic high for the department and an improvement since 2001 (Marcus and Otis, 2015). As for the NYPD, the latest data I was able to find is from 2009 and revealed an increase of female police officers in $40 \%$ since 2001, according to Police Commissioner Raymond W. Kelly (New York Police Department, 2009). These numbers reflect an increasing number of women being admitted both in the FDNY and the NYPD, but the gender gap is still astonishingly high.

Considering how the American Hero myth has such intrinsic origins that are deeply engrained in the American subconscious, one could assume that this myth is static, generating narratives that perpetuate the "American Monomyth" concept. To understand how this myth has been recently presented, I will focus on two popular movies that came out in 2014: American Sniper and Interstellar. Although both films deal with this notion of what (and who) is an American hero, I will be focusing more deeply on American Sniper due to its autobiographical character and representation of real life events.

In American Sniper, directed by Clint Eastwood, the presence of the "American Monomyth" is very noticeable: the selfless unexpected hero puts upon himself the responsibility of restoring the community order against all obstacles. The narrative that was built around Chris Kyle fits this pattern: an unknown humble ranch worker in Texas who then becomes a Navy Seal and is deployed to the Iraq war, where he fights to protect his country and is considered the most lethal sniper in US history. But was Chris Kyle an American hero?

In his memoir, he claimed that "shooting the machine gun was fun!" (Kyleet al., 2013: 96) and dwelled on how he "couldn't give a flying fuck about the Iraqis" (Kyle et al., 2013: 271) because he "hated the damn savages" he'd been fighting (Kyle et al., 2013: 301). In fact, Chris Kyle seemed to adopt the same one-dimensional perspective on the Iraq war perpetuated by George W. Bush. Given the way Iraq had not invaded or attacked the US, when deciding to attack that country, Americans became the aggressors. However, in the American rhetoric, the aggressors were the heroes while the Iraqis, who were protecting themselves against the invaders, were the villains and "the savages". This was a dangerous position that legitimized the dehumanization of Iraqis, an act that Chris Kyle himself engaged in: "Every person I killed I strongly believe 
that they were bad [...] When I do go face God there is going to be lots of things I will have to account for, but killing any of those people is not one of them." (Hegarty, 2012).This dehumanization of the Iraqi people is also very apparent in the film as they are portrayed as coldhearted vicious monsters (American Sniper, 2014). This portrayal ended up encouraging some Americans to tweet about their desire to take action against Iraqis. As Kolhatkar reports: "American Sniper makes me wanna go shoot some fuckin' Arabs", "Great fucking movie and now I really want to kill some fucking ragheads" (2015). Nonetheless, the movie has divided the country mainly in two. Some Americans say Chris Kyle was a hero while others believe he was far from being one. Representing one side we have Kolhatkar demystifying the film narrative based on true facts of Chris Kyle's life. American Sniper exemplifies a sense of macho, white male braggadocio that is symbolic of all that is wrong with the right-wing, pro-war, pro-gun, bully culture of the United States. Should we really be surprised that both the American public and the Academy are rewarding a film about a man who, judging by his own words, appeared to be a psychotic mass murderer (2015)?

On the other side, there is Lauri B. Regan supporting the acts committed against the Iraqis and the American need of heroes such as Kyle to fight 'the enemy'. While watching American Sniper, the viewer is observing events that occurred recently and that may well take place tomorrow. There is no escaping the fact that the "evil f-king savages", as Kyle so aptly calls them are alive and well - and coming for us (2015). Judging by the way the film celebrates Kyle as a hero, Clint Eastwood is clearly on the latter side, sharing a warped view of the events.

We have seen before how women do not have a leading role in the "American Monomyth" narratives. American Sniper is not an exception. Taya Kyle, the sniper's wife, is portrayed solely as an attentive and concerned wife and mother, in which her only purpose is to be a support system to Chris. Again, while men are heroicized, women are pushed to the background.

In Interstellar, another movie coming out in late 2014, the "American Monomyth" narrative breaks this tradition of women being pushed to the background. In this respect, the film does something innovative: Cooper, an 'average Joe' farmer, becomes the unlikely hero of a space mission to save humanity and his heroicization process 
begins when he succeeds. Nonetheless, unlike in other "American Monomyth" narratives, as Cooper is elevated to hero status, the women in his life are not pushed to the background. Instead, his daughter, Murph (one of the two female main characters) goes through the heroicization process along with him and eventually becomes the real hero of the story (Interstellar, 2014).

Both films demonstrate that Americans still haven't moved "beyond mythical consciousness" (Jewett and Lawrence, 2002: 6) - they're still trapped in the "endlessly repeated story of innocent communities besieged by evil outsiders" (Jewett and Lawrence, 2002: 16-17) who are then saved by an average Joe.

Still with no release date as of this moment is the movie "Ashley's War", an adaptation of the homonymous book telling the story of a team of women soldiers fighting on the front line in Afghanistan (Brown, 2015). In what is expected to be a female heavy film, it will be interesting to see how the American hero myth is explored and what role(s) women will play in it.

\section{Conclusion}

Recently after Susan Faludi published her book, Rebecca Traister accused her of seeing a "vast national conspiracy to put women back in the kitchen and alpha males like John Wayne [...] back in their lost positions of power" (2007). I hope this paper has demonstrated how I disagree with Traister's assessment. Naming this process a conspiracy would mean that the agents perpetrating it are entirely aware of it. As I have showed, due to the trauma inflicted upon Americans with 9/11, resorting to history and national myths to make sense of what happened came as a coping process. These myths, particularly captivity narratives and the patriarchy engrained in Puritan America, helped giving rise to the American hero myth, where men are the strong and manly heroes and women, the powerless and weak victims in need of rescue. With the resurgence of this American hero myth, women were portrayed as the victims who did not have a primary role in the heroicization process of regular civilians, firefighters and police officers. As the manly heroes were being exposed to the public sphere, the female invisibility cloak pushed women to the private sphere. Even in the very particular occasions when women were the protagonists, what propelled them to the 
foreground concerned their dutiful roles as mothers and wives, in a process that only pushed them even more to the private sphere. These myths and all of their consequences to women are still present in the American imaginary. More than a conspiracy, Faludi was trying to alert us to the dangers of an internalized misogyny. Through the rebirth of the American hero myth perspective, I have tried to explain how this engrained prejudice against women also appears to intensify and gain momentum in times of crisis. We need to be aware of these mechanisms and processes so that, in the future, we can prevent women from being pushed to the background while men are distinguished as heroes. Human beings are capable of great deeds - why should not both men and women be celebrated for their bravery amidst chaos?

\section{References}

Alexander, Jeffrey Charles; Eyerman, Ron; Giesen, Bernhard; Smelser, Neil; Sztompka, Piotr (2004), Cultural Trauma and Collective Identity. Berkeley, California: University of California Press.

Allen, Charlotte (2012), "Newtown Answers", National Review, 19 December. Accessed on 14.07.2015, at http://www.national review.com/article/335996/newtown-answers-nro-symposium.

Ashlock, Alex (2011), "A Reluctant 9/11 Hero Looks Back", Boston's NPR News Station, 9 September. Accessed on 14.07.2015,at http://hereandnow.wbur.org/2011/09/09/benfante-reluctant-hero.

Baelo-Allué, Sonia (2012),"9/11 and the Psychic Trauma Novel: Don Delillo's Falling Man", Atlantis: Journal of the Spanish Association of Anglo-American Studies, 34, 63-79. Accessed on 14.07.2015, athttp://www.atlantisjournal.org/old/ARCHIVE/34.1/SBAELO_2012.pdf.

Boon, Jon (2009), "Afghanistan passes 'barbaric' law diminishing women's rights", The Guardian, 14 August. Accessed on 14.07.2015,at http://www.theguardian.com/world/2009/aug/14/afghanistan womens-rights-rape.

Brown, Kat (2015), "Reese Witherspoon to star in 'female American Sniper'", The Telegraph, 12 March. Accessed on 14.07.2015,at http://www.telegraph.co.uk/culture/film/film-news/11467280/ReeseWitherspoon-to-star-in-female-American-Sniper.html.

Bunting, Madeleine (2001), "Women and War", The Guardian, 20 September. Accessed on 14.07.2015, at

http://www.theguardian.com/education/2001/sep/20/socialsciences.hi ghereducation.

Bush, George Walker(2001a), "Address to the Nation on the Terrorist Attacks", The American Presidency Project, 11 September. Accessed on 14.07.2015, at http://www.presidency.ucsb.edu/ws/index.php?pid=58057\&st=\&st1=. 
Bush, Laura (2001), "Radio Address by Mrs. Bush", The American Presidency Project, 17 November. Accessed on 14.07.2015,at http://www.presidency.ucsb.edu/ws/?pid=24992.

Caruth, Cathy (1996), Unclaimed Experience: Trauma, Narrative and History. Baltimore, Maryland: The Johns Hopkins University Press.

Charen, Mona (2001), "Hooray for Men”, Townhall.com, 31 December. Accessed on 14.07.2015,at http://townhall.com/columnists/monacharen/2001/12/31/hooray_for_men.

CNN Library (2015), "September 11th Fast Facts". Accessed on 14.07.2015,at http://edition.cnn.com/2013/07/27/us/september-11-anniversary-fast-facts/.

Dale, Richard (dir.) (2006), Bampfield, Andrew; Fields, Ed (script), Inside the Twin Towers, $1 \mathrm{~h} 38$.

Derounian-Stodola, Kathryn Zabelle (1994), "The Indian Captivity Narratives of Mary Rowlandson and Olive Oatman: Case Studies in the Continuity, Evolution, and Exploitation of Literary Discourse", Studies in the Literary Imagination, 27(1), 33-46.

Dollarhide, Maya (2001a), “Using E-mail List, Shulock Finds 3,000 Volunteers", Womensenews.org, 5 November. Accessed on 14.07.2015,at http://womensenews.org/story/our-history/011105/using-email-list-shulock-finds-3000-volunteers?page=0,1.

Dollarhide, Maya (2001b), "Ironworker George Cleared Debris With Her Hands", Womensenews.org, 22 October. Accessed on 14.07.2015, at http://womensenews.org/story/ourhistory/011022/ironworker-george-cleared-debris-her-hands.

Drexler, Peggy(2002), "This Time, the Brother Is a Sister",Womensenews.com, 3 April. Accessed on 14.07.2015,athttp://womensenews.org/story/commentary/020403/time-the-brother-sister.

Eastwood, Clint (dir.) (2014), Hall, Jason (script), American Sniper, 2 h13.

Faludi, Susan (2007), The Terror Dream: what 9/11 revealed about America. London: Atlantic Books.

Ferguson, David (2015), “Demoted Catholic cardinal: 'Radical feminists' are to blame for pedophile priests", Raw Story, 7 January. Accessed on 14.07.2015,at http://www.rawstory.com/2015/01/demoted-catholic-cardinal-radical-feminists-are-to-blame-forpedophile-priests/.

Ganzevoort, R. Ruart, Veerman, Alexander L. (2001), “Communities Coping with Collective Trauma". Paper presented at the Conference of the International Association for the Psychology of Religion, Soesterberg, The Netherlands, September 2001.

Gibbs, Nancy (2001), "The Swords of Justice”, Time Magazine, 1 October. Accessed on 14.07.2015,at http://content.time.com/time/world/article/0,8599,2047952,00.html.

Goldstein, Laurie (2001), "Falwell: blame abortionists, feminists and gays", The Guardian, 19 September. Accessed on 14.07.2015,athttp://www.theguardian.com/world/2001/sep/19/september11.usa9.

Good, Alastair (2011), "September 11: Mexico's forgotten 9/11 victim", The Telegraph, 6 September. Accessed on 14.07.2015, at http://www.telegraph.co.uk/news/worldnews/september-11attacks/8745821/September-11-Mexicos-forgotten-911-victim.html.

Hegarty, Stephanie (2015), "What goes on in the mind of a sniper?", BBC News, 25 January. Accessed on 14.07.2015, at http://www.bbc.com/news/magazine-16544490. 
Infoplease (2007), "Live Births and Birth Rates, by Year". Accessed on 14.07.2015,athttp://www.infoplease.com/ipa/A0005067.html.

Jewett, Robert; Lawrence, John Shelton (2002), The Myth of the American Superhero. Grand Rapids, Michigan: William B. Eerdmans Publishing Company.

Kolhatkar, Sonali (2015), “'American Sniper': American Hero or American Psycho?'”, Truthdig, 22 January. Accessed on 14.07.2015, at http://www.truthdig.com/report/item/american_sniper_american_hero_or_american_psycho_2015 0122.

Kyle, Chris; McEwen, Scott; DeFelice, Jim (2013), American Sniper: The Autobiography of the Most Lethal Sniper in U.S. Military History. New York: Harper Collins.

Lombardi, Chris (2002), "'Partners of Sept. 11 Victims Denied Compensation'”, Womensenews.org, 19 January. Accessed on 14.07.2015, at http://womensenews.org/story/lesbiantransgender/020119/partners-sept-11-victims-denied-compensation.

Marcus, Chelsea Rose; Otis, Ginger Adam (2015), "'FDNY welcomes 305 rookie firefighters, including 3 women'”, Daily News, 5 May. Accessed on 14.07.2015, athttp://www.nydailynews.com/newyork/fdny-wel comes-305-new-firefighters-including-3-women-article-1.2211289.

Miller, Kay (2002), “The Invisible Women Firefighters Of Ground Zero”, Star Tribune - Minneapolis, 13 January. Accessed on 14.07.2015, at http://www.rense.com/general19/zero.htm.

New York Police Department (2009), "NYPD Celebrates Women in Policing”. Accessed on 14.07.2015, at http://www.nyc.gov/html/nypd/html/pr/pr_2009_ph07.shtml.

Nolan, Christopher (dir.) (2014), Nolan, Christopher; Nolan, Jonathan (script), Interstellar, 2 h49.

Page, Susan (2004), "Bush is opening doors with a diverse Cabinet", USA Today 12 September. Accessed on 14.07.2015, at http://usatoday30.usatoday.com/news/washington/2004-12-09-diverseusat_x.htm.

Prince, Richard (2011), "No Blacks Pictured in 9/11 Commemorative", The Root 10 September. Accessed on 14.07.2015, at http://www.theroot.com/blogs/journalisms/2011/09/no_blacks_pictured_in_911_commemorative. html.

Raimi, Sam (dir.) (2002), Koepp, David (script), Spider-Man, $2 \mathrm{~h} 01$.

Regan, Lauri B. (2015), "An American Hero... and Obama”, American Thinker, 20 January. Accessed on 14.07.2015, http://www.americanthinker.com/articles/2015/01/an_american_hero_and_obama.html.

Shannon-Missal, Larry (2015), “The Equalizer Knows No Equal: Denzel Washington is America's Favorite Movie Star". Accessed on 14.07.2015, at http://www.harrisinteractive.com/NewsRoom/Harris Polls/tabid/447/mid/1508/articleld/1544/ctl/R eadCustom\%20Default/Default.aspx.

Sielke, Sabine (2013), "Why '9/11 is [not] unique,' or: Troping Trauma”, Amerikastudien, 55(3), 385-408. Accessed on 14.07.2015, at http://www.nas.uni-bonn.de/people/ssie_unique. 
Slotkin, Richard (1996), Regeneration through Violence. Middletown, Connecticut: Wesleyan University Press.

Sontag, Susan (2001), "Tuesday, and After", The New Yorker, 24 September. Accessed on 14.07.2015, athttp://www.newyorker.com/magazine/2001/09/24/tuesday-and-after-talk-of-the-town.

Tickner, J. Ann (2002), "Feminist Perspectives on 9/11", International Studies Perspectives, 3, 333-350.

Traister, Rebecca (2007), "The 9/11 backlash against women", Salon, 3 October. Accessed on 14.07.2015, at http://www.salon.com/2007/10/03/faludi/.

Wilkinson, Janet (2014), “It's Time To Class Feminism As a Terrorist Group”. Accessed on 14.07.2015,at https://www.change.org/p/the-government-its-time-to-class-feminism-as-a-terrorist-group.

Women's Media Center (2015), "The Status of Women in the US Media 2015". Accessed on 14.07.2015,at http://wmc.3cdn.net/83bf6082a319460eb1_hsrm680x2.pdf.

Worcester, Kent (2011), "New York City, 9/11, and Comics", Radical History Review, 2011(111), 139-154.

Young, Cathy (2002), “Feminism's Slide since September 11", Reason Magazine, 17 September. Accessed on 14.07.2015, at http://reason.com/archives/2002/09/17/feminisms-slide-sinceseptember 
